\title{
Tratamentos de feridas cutâneas experimentais com extrato e óleo de copaíba
}

Juliana de Moura Alonso, Debora Perrone Kauer, Claudia Helena Pellizzon, Ana Liz Garcia Alves, Marcos Jun Watanabe, Celso Antônio Rodrigues, Carlos Alberto Hussni"

Universidade Estadual Paulista (UNESP), Botucatu, SP, Brasil

*Autor correspondente

e-mail: cahussni@fmvz.unesp.br

\section{Resumo}

Feridas cutâneas apresentam elevada incidência na espécie equina. A copaíba (Copaifera langsdorffii) é uma árvore encontrada nas regiões norte e nordeste do Brasil, que tem sido estudada como fonte fitoterápica na cicatrização de feridas. 0 objetivo deste estudo foi avaliar os tratamentos com o extrato hidroalcoólico e com o óleo-resina de copaíba em feridas cutâneas experimentalmente induzidas em equinos. Foram utilizados seis equinos adultos, submetidos à indução bilateral de quatro feridas circulares de pele de $2 \mathrm{~cm}$ de diâmetro. As feridas foram produzidas com auxílio de punch, dispostas linearmente na região lombar direita e esquerda. Foram utilizados quatro tratamentos tópicos: solução fisiológica (controle), creme Lanette (veículo puro), creme à base de extrato hidroalcoólico de copaíba a $10 \%(\mathrm{EH})$ e creme à base de óleo-resina de copaíba a 10\% (OL). Os tratamentos foram dispostos em diferentes sequências em cada animal, sendo combinados alternadamente no sentido crânio-caudal. As diferentes combinações foram realizadas a fim de se minimizar a influência das diferentes taxas de retração observadas ao longo da região dorsal dos equinos A região lombar direita foi destinada à avaliação macroscópica da cicatrização, tempo total de cicatrização e retração, através da planimetria sequencial. 0 lado esquerdo foi destinado à análise histopatológica, que se deu através da realização de biópsias nos dias 3, 7, 14 e 21. As feridas se apresentaram macroscopicamente semelhantes nos primeiros três dias de tratamento, caracterizando o processo inflamatório inicial. Na segunda fase do processo cicatricial ( $3^{\circ}$ e $\left.7^{\circ} \stackrel{0}{d i a}\right)$, as feridas do tratamento controle mostraram-se significantemente menores em relação às feridas tratadas com copaíba (EH e OL), sugerindo que esses tratamentos interferiram negativamente na taxa de retração neste período. Apesar das feridas tratadas com copaíba ou creme base se mostrarem maiores neste período, não houve diferença significativa no tempo total de cicatrização entre os tratamentos. A partir das análises microscópicas, foi observado que as feridas tratadas com copaíba apresentaram presença de vasos mais calibrosos e melhor reorganização 
tecidual no $14^{\circ}$ e $21^{\circ}$, destacando-se positivamente o tratamento com OL. A partir dos resultados obtidos, foi possível concluir que os tratamentos com OL e EH não resultaram em diminuição significativa do tempo total de cicatrização e resultaram em atraso na contração da ferida nos primeiros sete dias. A utilização do OL demonstrou-se indicado no tratamento de feridas em equinos após a fase inflamatória, ao sétimo dia de tratamento, pois não interferiram na retração e promoveram melhor qualidade do tecido cicatricial.

Palavras-chave: Copaíba. Cicatrização. Equinos.

Agradecimentos: à CNPq/PIBIC - UNESP. 